\title{
Global Cultural Law and Policy in the Age of Ubiquitous Internet
}

MIRA BURRI

Digital technologies and the Internet in particular have transformed the ways we create, distribute, use, reuse and consume cultural content; have impacted on the workings of the cultural industries, and more generally on the processes of making, experiencing and remembering culture in local and global spaces. Yet, few of these, often profound, transformations have found reflection in law and institutional design. Cultural policy toolkits, in particular at the international level, are still very much offline/analogue and conceive of culture as static property linked to national sovereignty and state boundaries. The article describes this state of affairs and asks the key question of whether there is a need to reform global cultural law and policy and if yes, what the essential elements of such a reform should be.

\section{Forthcoming in the International Journal of Cultural Property.}

\section{FNSNF}

FONDS NATIONAL SUISSE

SCHWEIZERISCHER NATIONALFONDS FONDO NAZIONALE SVIZZERO
SWISS NATIONAL SCIENCE FOUNDATION
Die Nationalen Forschungsschwerpunkte (NFS) sind ein Förderinstrument des Schweizerischen Nationalfonds. Les Pôles de recherche nationaux (PRN) sont un instrument d'encouragement du Fonds national suisse. The National Centres of Competence in Research (NCCR) are a research instrument of the Swiss National Science Fondation. 


\title{
Global Cultural Law and Policy in the Age of Ubiquitous Internet
}

\begin{abstract}
Mira Burri*
Digital technologies and the Internet in particular have transformed the ways we create, distribute, use, reuse and consume cultural content; have impacted on the workings of the cultural industries, and more generally on the processes of making, experiencing and remembering culture in local and global spaces. Yet, few of these, often profound, transformations have found reflection in law and institutional design. Cultural policy toolkits, in particular at the international level, are still very much offline/analogue and conceive of culture as static property linked to national sovereignty and state boundaries. The article describes this state of affairs and asks the key question of whether there is a need to reform global cultural law and policy and if yes, what the essential elements of such a reform should be. The paper is informed by the ongoing and vibrant digital copyright and creativity discourse ${ }^{1}$ but seeks to address also the less discussed non-intellectual property (IP) tools of the cultural policy package. It thematizes the complexity and the interconnectedness of different fields of policy-making, as various decisions critical to cultural processes are made by institutions without cultural mandate. While this problem is not entirely new and is naturally triggered by the intrinsic duality of cultural goods and services, the article argues that the digital networked environment has only accentuated complexity, spillover effects and unintended consequences. The question is how to navigate this newly created and profoundly fluid space, so as to ensure the preservation and sustainable provision of culture. The article hopes to contribute to the process of finding answers to this taxing question by identifying a few essential elements that need to be taken into consideration when designing future-oriented cultural policy.
\end{abstract}

\footnotetext{
* Senior research fellow and lecturer in law, World Trade Institute, University of Bern. The author is deeply grateful to the discussions and feedback received during the Conference "Thinking About Cultural Property: The Legal and Public Policy Legacies of John Henry Merryman", 9-10 November 2013, Stanford University.

${ }^{1}$ See e.g. Paul Edward Geller, "Copyright History and the Future: What's Culture Got to Do With It?", Journal of the Copyright Society of the USA 47 (2000), 209-264; Julie E. Cohen, "Copyright, Commodification, and Culture: Locating the Public Domain", in Lucie Guibault and Bernt Hugenholtz (eds.), The Future of the Public Domain (Alphen aan den Rijn: Kluwer Law International), 121-166; Madhavi Sunder, "IP3", Stanford Law Review 59:2 (2006), 257-332; Julie E. Cohen, "Creativity and Culture in Copyright Theory", UC Davis Law Review 40:3 (2007), 1151-1205.
} 


\section{Setting the scene: a few remarks}

The international law of culture is a complex domain that encompasses a vast amount of treaties. They are both an expression of "cultural nationalism" as the right of the nation state to protect its own culture and of "cultural internationalism" as the right of the international community to protect components of common human culture ${ }^{2}$ - of the past and present, in times of war and peace. This of course is a highly stylized picture, which masks the complexity of the legal norms and institutions, ${ }^{3}$ as well as the various contentions around the definitions of what culture is, what a nation is and whom culture belongs to, as well as around the underlying sets of rights and how they can be enforced. ${ }^{4}$

Globalization as the process of intensifying the movement of goods, services, capital, people and ideas across borders, has only made things more complex and contentious. On the one hand, it is evident that the nation state is no longer the exclusive forum defining cultural policies. The production of cultural policy now happens across many sites and with the participation of various actors, many of them not related to the state. On the other hand, the inherent duality of cultural goods and services as such that have economic value and can be traded, while being by their very nature "vehicles of identity, values and meaning", 5 has meant that both economic and non-economic interests are constantly affected.

In this context, it should be stressed that law-making, in particular at the international level, has not progressed with similar speed in these two areas. The institutionalization of economic globalization has advanced much more swiftly and led to closer, more binding forms of international cooperation, epitomized above all by the rules of the World Trade Organization (WTO). In this evolution, there have been only scant attempts to reconcile the two sides of cultural goods and services and the policies targeted at them. The majority of cultural instruments have above all striven to secure carve-outs where states can assert their sovereignty on cultural matters. ${ }^{6}$

\footnotetext{
2 John Henry Merryman, “Two Ways of Thinking about Cultural Property”, The American Journal of International Law 80:4 (1986), 831-853.

${ }^{3}$ See e.g. Craig Forrest, International Law and the Protection of Cultural Heritage (Abingdon, UK: Routledge, 2010).

${ }^{4}$ See e.g. Madhavi Sunder, “Cultural Dissent”, Stanford Law Review 54 (2001), 495-567; Naomi Mezey, "The Paradoxes of Cultural Property”, Columbia Law Review 107 (2007), 2004-2046; Pippa Norris and Ronald Inglehart, Cosmopolitan Communications: Cultural Diversity in a Globalized World (Cambridge: Cambridge University Press, 2009); Derek Gillman, The Idea of Cultural Heritage, revised edn. (Cambridge: Cambridge University Press, 2010); Derek Fincham. "The Distinctness of Property and Heritage", Penn State Law Review 115:3 (2011), 641-684. See also John Henry Merryman (ed.), Thinking about the Elgin Marbles: Critical Essays on Cultural Property, Art and Law, 2nd edn. (Alphen aan den Rijn: Wolters Kluwer, 2009).

${ }^{5}$ Article 1(g), UNESCO, Convention on the Protection and Promotion of Diversity in Cultural Expressions, 20 October 2005 [hereinafter the UNESCO Convention or the 2005 UNESCO Convention].

${ }^{6}$ See e.g. Mary E. Footer and Christoph Beat Graber, "Trade Liberalisation and Cultural Policy", Journal of International Economic Law 3 (2000), 115-144.
} 
Although many have argued that international law is in crisis and there is little if no movement ahead, ${ }^{7}$ the past decade has been marked by significant developments in international cultural law. It suffices to mention three recent and key acts of this proactive treaty-making: in 2003, delegates of 190 countries adopted the Convention on the Safeguarding of Intangible Cultural Heritage ${ }^{8}$ in 2005 , also under the auspices of the United Nations Educational, Scientific and Cultural Organization (UNESCO), agreement was reached on the Convention on the Protection and Promotion of the Diversity of Cultural Expressions, ${ }^{9}$ and in 2007, the General Assembly of the United Nations adopted the Declaration on the Rights of Indigenous Peoples. ${ }^{10}$

What appears to be a common feature of these treaties is that they are relatively broadly formulated and definitively go beyond trade in cultural objects. The 2005 UNESCO Convention on Cultural Diversity has particularly high goals. It aims at nothing less than the sustainability of diversity of cultural expressions taking a comprehensive and dynamic perception of culture. This is a marked shift from the defensive slogan of "cultural exception", which dominated the trade and culture discourse for some thirty years, during and after the WTO Uruguay Round of negotiations (1986-1994). ${ }^{11}$

Unfortunately, even this bolder act of international treaty-making fails to provide guidance as to the appropriate tools to be applied in order to better serve the global public good of a diverse cultural environment. The reasons for this are multiple. An important one relates to the longer narrative of juxtaposing trade and culture and the actual political battle triggered by the diverging interests on matters of trade and culture during the Uruguay Round of negotiations, which led to the establishment of the WTO. ${ }^{12}$ The second source of disappointment is the very act of the 2005 UNESCO Convention on Cultural Diversity. Although the Convention had an incredibly ambitious agenda and was widely applauded at the outset, with the benefit of hindsight its impact can

\footnotetext{
${ }^{7}$ See e.g. Hilary Charlesworth, "International Law: A Discipline of Crisis", The Modern Law Review 65:3 (2002), 377-392; Rafael Domingo, "The Crisis of International Law", Vanderbilt Journal of Transnational Law 42 (2009), 1542-1593; Joel P. Trachtman, The Future of International Law: Global Government (Cambridge: Cambridge University Press, 2013).

${ }^{8}$ United Nations, Convention for the Safeguarding of the Intangible Cultural Heritage, U.N. Doc. MISC/2003/CLT/CH/14, 17 October 2003.

9 As of 20 November 2013, 133 countries had ratified the Convention. See http://portal.unesco.org/la/convention.asp? KO=31038\&language=E (last accessed 10 February 2014).

${ }^{10}$ United Nations, Declaration on the Rights of Indigenous Peoples, U.N. Doc. A/RES/61/295, 13 September 2007.

${ }^{11}$ At that time several countries, with the European Union (EU) and Canada at the forefront, fought the so-called "exception culturelle" battle. As the name suggests, it aimed at exempting any product or service that is culture-related from the rules of the negotiated WTO Agreements. The prime focus of the campaign was on the exclusion of audiovisual services - i.e. films, television programmes, video and sound recordings, as these were conventionally highly protected sectors and faced significant competition from the US entertainment industry. For details, see Keith Acheson and Christopher Maule, "Convention on Cultural Diversity", Journal of Cultural Economics 28 (2004), 243-256; Mira Burri, "Cultural Diversity as a Concept of Global Law: Origins, Evolution and Prospects", Diversity 2 (2010), 1059-1084.

12 Burri, ibid.
} 
be assessed as modest. ${ }^{13}$ We do not (as yet) see any legal or policy reform either as a result of the Convention's own implementation efforts ${ }^{14}$ or as to the Convention's impact on the WTO regime, which it was supposed to counterbalance. ${ }^{15}$ What the UNESCO Convention as a minimum does is to confirm (yet again) national sovereignty in cultural matters and preserve the status quo. ${ }^{16}$

This comes as no surprise, however, considering the complexities in the matrix of trade, culture, media, intellectual property and human rights ${ }^{17}$ and the starkly different sensibilities of the negotiating parties. ${ }^{18}$ It is also fair to say that the global cultural policy discourse has been marked from its outset by a deeply convoluted understanding of the effects of trade, and more broadly of economic globalization, on culture. ${ }^{19}$ The common (and often loud) statements are that cultural diversity is becoming impoverished and almost extinguished as the globalized flow of easy entertainment coming from Hollywood dominates and homogenizes. ${ }^{20}$ The perceived peril for small art productions and local and indigenous culture is deemed immense and worthy of the state's counteraction. This picture is conventionally seen as being black and white; the many nuances of the complex commerce and culture interlinks are often missed out. Parties on both sides find examples to support their positions. Exponents of cultural protectionism tend to pick up their facts from the film markets, where the US clearly dominates and where the power of big budget and aggressive marketing is self-evident. The free market proponents make their case by using examples

\footnotetext{
${ }^{13}$ For detailed critique, see Rachael Craufurd Smith, "The UNESCO Convention on the Protection and Promotion of Cultural Expressions: Building a New World Information and Communication Order?", International Journal of Communication 1 (2007), 24-55; also Mira Burri, "Trade and Culture in International Law: Paths to (Re)conciliation", Journal of World Trade 44:1 (2010), 49-80.

${ }^{14}$ Mira Burri, "The UNESCO Convention on Cultural Diversity: An Appraisal Five Years after its Entry into Force", International Journal of Cultural Property 20 (2014), 1-24.

${ }^{15}$ See e.g. Christoph Beat Graber, "The New UNESCO Convention on Cultural Diversity: A Counterbalance to the WTO", Journal of International Economic Law 9:3 (2006), 553-574.

${ }^{16}$ See e.g. Craufurd Smith, supra note 13.

${ }^{17}$ See comprehensively, Laurence R. Helfer and Graeme W. Austin, Intellectual Property and Human Rights: Mapping the Global Interface (Cambridge: Cambridge University Press, 2011).

${ }^{18}$ Craufurd Smith, supra note 13, at 30-32. See also Caroline Pauwels, Jan Loisen and Karen Donders, "Culture Incorporated; or Trade Revisited? How the Position of Different Countries Affects the Outcome of the Debate on Cultural Trade and Diversity", in Nina Obuljen and Joost Smiers (eds.), UNESCO's Convention on the Protection and Promotion of the Diversity of Cultural Expressions: Making It Work (Zagreb: Institute for International Relations, 2006), 125-158. See in general, Kal Raustiala, "Form and Substance in International Agreements", The American Journal of International Law 99 (2005), 581-614.

${ }^{19}$ For an overview of the different positions, see Pierre Sauvé and Karsten Steinfatt, "Towards Multilateral Rules on Trade and Culture: Protective Regulation or Efficient Protection?", in Productivity Commission and Australian National University (eds.), Achieving Better Regulation of Services (Canberra: AusInfo, 2000), 323-346; Ian Slotin, "Free Speech and the Visage Culturel: Canadian and American Perspectives on Pop Culture Discrimination", Yale Law Journal 111:8 (2002), 2289-2320; Sean Pager, "Beyond Culture vs. Commerce: Decentralizing Cultural Production to Promote Diversity through Trade", Northwestern Journal of International Law and Business 31 (2011), 63-136.

${ }^{20}$ See e.g. Christoph Beat Graber, Handel und Kultur im Audiovisionsrecht der WTO (Bern: Staempfli Publishing, 2003).
} 
of local musicians gone global or the success of documentary productions. ${ }^{21}$ While the truth is somewhere between the two extremes, ${ }^{22}$ the discussion on "trade" and "non-trade" values is so extremely politicized that it renders any practical solution impossible. ${ }^{23}$ Answers to critical questions such as "diversity of what?" and "diversity how?" remain unanswered too. This is regrettable as cultural diversity as a global public good does have its virtues and may offer a so-far unprecedented platform to actually address essential cultural concerns at the international level.

\section{The digital disconnect}

Regardless of the success so far or the potential for success of all these instruments at the international level; regardless also of their underlying justifications in the sense of whether it is right to protect culture through the nation state, and very often against another culture, ${ }^{24}$ the central argument this article aims to make is that they are all grounded in the analogue/offline age they are "culture law 1.0". Even the newer international treaties, listed at the beginning of this piece, do not mention digital technologies as an essential channel for their implementation. What is more their drafters have failed to consider the broader societal effects of digital technologies and the Internet in particular.

Describing the "digital" is not trivial, as it has triggered and continues to cause many and multi-directional effects. ${ }^{25}$ For the sake of brevity, I use the concept of a transformed "information and communication environment", as so aptly developed by Yochai Benkler. ${ }^{26}$ This terminological shortcut allows us to unpack for the purpose of the article all those changes that are associated with the affordances of digital technologies, such as: instantaneous communication to millions at basically no cost, low threshold of participation, perfect copies, no tangible medium, no scarcity in cyberspace, completely different organization of information in cyberspace. But also and more importantly, it enables us to refer to the societal implications of these possibilities, which in a most immediately relevant way, transform the very ways we create, distribute, access, use and reuse cultural content; the ways we participate individually or

\footnotetext{
${ }^{21}$ J.P. Singh, "Culture or Commerce? A Comparative Assessment of International Interactions and Developing Countries at UNESCO, WTO, and Beyond", International Studies Perspectives 8 (2007), $36-53$.

${ }^{22}$ See Antony Giddens, Runaway World: How Globalisation is Reshaping Our Lives (Abingdon, UK: Routledge, 2002); Tyler Cowen, Creative Destruction: How Globalization Is Changing the World's Cultures (Princeton, NJ: Princeton University Press, 2002), at 146; Tyler Cowen, In Praise of Commercial Culture (Cambridge, MA: Harvard University Press, 1998), in particular at 15-43.

${ }^{23}$ See e.g. Christopher M. Bruner, "Culture, Sovereignty, and Hollywood: UNESCO and the Future of Trade in Cultural Products", International Law and Politics 40 (2008), 351-436; Sunder, supra note 4.

${ }^{24}$ See e.g. Sunder; Norris and Inglehart; Mezey, all supra note 4.

${ }^{25}$ See e.g. Haidy Geismar, "Defining the Digital", Museum and Anthropology Review 7:1/2 (2013), 254-263.

${ }^{26}$ Yochai Benkler, The Wealth of Networks: How Social Production Transforms Markets and Freedom (New Haven, CT: Yale University Press, 2006), at 2.
} 
as part of a group in cultural processes; as well as change the transparency of cultural symbols and the ways they circulate in local and global contexts. ${ }^{27}$

Yet, it should be clear that I do not mean this as a sort of web-utopianism and a conception of digital technologies as a panacea for sustaining and enriching cultural practices. Indeed, many of the early cyber-hype theories have not found enough support in reality.

One of them, the so-called "long tail" theory, preached naturally generated diversity, as the reduced barriers to entry allow new market players to position themselves and make use of niche markets, which are economically viable in the digital ecosystem due to the dramatically falling storage, distribution and search costs. ${ }^{28}$ Thus, supply and demand meet not only for "mainstream" products available in the "head" of the snake, but also for many other products, now available in the ever-lengthening "tail". So that for instance indigenous music performers can become globally active, known and potentially commercially successful. $^{29}$

Even greater has been the promise of user-created content (UCC) as a powerful tool of democratization of content production and distribution. UCC, generated through the new type of "commons-based peer production" 30 can be said to embody the key media policy components of diversity, localism and noncommercialism, ${ }^{31}$ and in this sense could readily fulfil the key public interest objectives without additional intervention. Further, it is argued that the Internetfacilitated communication without intermediaries or other substantial access barriers has already created the always aspired to vibrant "marketplace of ideas". 32

Yet, despite the appeal of these transformative theories, evidence of current practices is much more nuanced. As for the long tail, it seems unclear, at least so far, whether an environment of unprecedented choice and sophisticated tools for identifying and accessing relevant content genuinely helps or harms the prospects for content that has not traditionally resided in the "head" ${ }^{33}$ One of the inherent characteristics of the new "attention economy" is the granular level of competition for audience, so that as online platforms offer the possibility of tracking the popularity of individual pieces of information and entertainment,

\footnotetext{
${ }^{27}$ Ibid. For a brief overview of these transformations, see e.g. Mira Burri, "Digital Technologies and Traditional Cultural Expressions: A Positive Look at a Difficult Relationship", International Journal of Cultural Property 17:1 (2010), 33-63.

${ }^{28}$ Chris Anderson, The Long Tail: Why the Future of Business is Selling More of Less (New York: Hyperion, 2006).

${ }^{29}$ Sean A. Pager, "Digital Content Productions in Nigeria and Brazil: A Case for Cultural Optimism", in Sean A. Pager and Adam Candeub (eds.), Transnational Culture in the Internet Age (Cheltenham, UK: Edward Elgar, 2012), 262-287.

${ }^{30}$ Benkler, supra note 26 , at $59-90$.

${ }^{31}$ Ellen P. Goodman, "Media Policy Out of the Box: Content Abundance, Attention Scarcity, and the Failures of Digital Markers", Berkeley Technology Law Journal 19 (2004), 1389-1472.

${ }^{32}$ Lawrence Lessig, Code: Version 2.0 (New York: Basic Books, 2006), at 245.

${ }^{33}$ Philip M. Napoli, "Persistent and Emergent Diversity Policy Concerns in an Evolving Media Environment: Toward a Reflective Research Agenda", in Sean Pager and Adam Candeub (eds.), Transnational Culture in the Internet Age (Cheltenham, UK: Edward Elgar, 2012), 167-181.
} 
editorial decisions may be distorted in favour of topics and genres that have mass appeal. ${ }^{34}$ Also, as global legacy media and Internet corporations merge, both horizontally and vertically, in the pursuit of better utilization of all available channels and platforms, diversity may in fact be lost. The question of real consumption is also a vexed one, as it appears that it remains limited to a handful of mainstream online sources that are, as a rule, professionally produced by white, educated men. ${ }^{35}$ While the positivity for user creativity is still strong, ${ }^{36}$ in the narrower sense of grassroots content production and its impact on democratic discourse, sceptical voices stress the dangers of balkanization and fragmentation of the public discourse. ${ }^{37}$

Despite this more nuanced approach and the acknowledgement that the Internet does not simply translate into a vibrant environment of cultural diversity; nor does it render cultural policies, as a matter of state intervention, obsolete, the argument that none or very few of these developments have been translated into the cultural policy debate and into thinking about appropriate legal design is still valid.

Another implication of digital media that is rarely considered is that the Internet has undoubtedly broadened the scope of cultural policy discussions, so decisions taken at all layers of the communication model - i.e. with regard to networks, applications and content ${ }^{38}$ - matter also for the attainment of cultural objectives, more or less immediately. In this sense, questions of net and search neutrality or interoperability, which were previously considered only peripheral to culture become relevant. Such questions affect not only the regulatory environment where cultural objectives are to be pursued but also its regulability - i.e. whether and how it can be regulated. ${ }^{39}$

The predicament for appropriate regulatory design in this context is that it needs to be holistic and consider multiple regulatory domains - such as telecommunications, information technology, standards, trade, intellectual

\footnotetext{
${ }^{34}$ Persephone Miel and Robert Farris, News and Information as Digital Media Come of Age (Cambridge, MA: The Berkman Center for Internet and Society, 2008), at 33. On the possible negative effects of online sharing on cultural diversity and the correlation with cultural quotas, see also Andres Hervas-Draney and Eli Noam, "Peer-to-Peer File Sharing and Cultural Trade Protectionism", Working Paper, 24 February 2013, available at http://ssrn.com/abstract=1793131 (last accessed 10 February 2014).

${ }^{35}$ Matthew Hindman, The Myth of Digital Democracy (Princeton, NJ: Princeton University Press, 2009).

${ }^{36}$ Benkler, supra note 26; also Yochai Benkler, The Penguin and the Leviathan: How Cooperation Triumphs over Self-Interest (New York: Crown Business, 2011).

${ }^{37}$ Cass R. Sunstein, Republic.com 2.0 (Princeton, NJ: Princeton University Press, 2007); also Cass Sunstein, Echo Chambers: Bush v. Gore Impeachment, and Beyond (Princeton, NJ: Princeton University Press, 2001) and more recently, Eli Pariser, The Filter Bubble: What the Internet is Hiding from You (London: Viking, 2011).

${ }^{38}$ Yochai Benkler, "From Consumers to Users: Shifting the Deeper Structures of Regulation toward Sustainable Commons and User Access", Federal Communications Law Journal 52 (2000), 561-579. Ellen P. Goodman and Anne H. Chen, "Digital Public Service Media Networks to Advance Broadband and Enrich Connected Communities", Journal on Telecommunications and High Technology Law 9 (2011), 81-124.

39 Jonathan Zittrain, The Future of the Internet - and How to Stop It (New Haven, CT: Yale University Press, 2008).
} 
property, Internet governance - each of which is marked by its own peculiar dynamics, power-plays and path dependencies. One should also consider the macro picture of governance, where the state is no longer the only actor but there is a "multiplication of agencies and forms of power that are active in the management of social systems". ${ }^{40}$ Cyber-governance has also brought its own specific set of hybrid governance models, ${ }^{41}$ while at the same time allowing effective unilateral state action in cyberspace, ${ }^{42}$ as well as regulation through code and technology in general. ${ }^{43}$ Such a profoundly fragmented environment renders the sustainable provision of global public goods particularly difficult, ${ }^{44}$ and takes the quest for regulatory coherence to a higher level of complexity. ${ }^{45}$

\section{From "culture law 1.0" towards "culture law 2.0"}

Admittedly, political decisions in the field of culture are not easy and neither is regulatory design. Despite the difficulties that this article has exposed, it is still worthwhile and important to ask whether the digital mismatch can be overcome, and if yes, what are the viable paths for reforming the global cultural law and policies.

\subsection{Opportunities abound?}

As possible paths for innovation one can look at the very characteristics of the digitally networked environment. As discussed earlier, although we are still in a world where old and new media co-exist, many of the processes of cultural creation, distribution and consumption have changed and one can highlight the following features as particularly relevant to the present context:

(i) proliferation of content and its different organization in cyberspace;

(ii) new ways of distributing, accessing and consuming content;

(iii) empowerment of the user and reduced role of intermediaries; both related to

(iv) the new modes of content production, where the user is not merely a consumer but is also an active creator, individually or as part of the community.

\footnotetext{
${ }^{40}$ Scott Burris, Michael Kempa and Clifford Shearing, "Changes in Governance: A CrossDisciplinary Review of Current Scholarship”, Akron Law Review 41:1 (2008), 1-66, at 12.

${ }^{41}$ Damien Tambini, Danilo Leonardi and Christopher T. Marsden, Codifying Cyberspace: Communications Self-regulation in the Age of Internet Convergence (Abingdon, UK: Routledge, 2008).

${ }^{42}$ Mira Burri, "Controlling New Media (without the Law)", in Monroe Price and Stefaan Verhulst (eds.), Handbook of Media Law and Policy (Abingdon, UK: Routledge, 2012), 327-342.

${ }^{43}$ Lawrence Lessig, Code and Other Laws of Cyberspace (New York: Basic Books, 1999); Lawrence Lessig, Code: Version 2.0 (New York: Basic Books, 2006); Roger Brownsword and Karen Yeung (eds.), Regulating Technologies: Legal Futures, Regulatory Frames and Technological Fixes (Oxford: Hart, 2008).

${ }^{44}$ See e.g. Eric Brousseau, Tom Dedeurwaerdere and Bernd Siebenhüner (eds.), Reflexive Governance for Global Public Goods (Cambridge, MA: MIT Press, 2012).

${ }^{45}$ United Nations, Fragmentation of International Law: Difficulties Arising from the Diversification and Expansion of International Law, Report of the Study Group of the International Law Commission, A/CN.4/L.682 (2006).
} 
In fact, although the legal framework has not been adjusted yet, there have already been some interesting experiments combining all these features. I refer here to one of them, Europeana, the leading EU project. Europeana is the European Digital Library, which is meant to function as a multilingual common access point to Europe's distributed cultural heritage. ${ }^{46}$ Europeana ${ }^{47}$ was launched in November 2008 and allows Internet users to search and gain direct access to digitized books, maps, paintings, newspapers, film fragments and photographs from Europe's cultural institutions. Presently some 30 million objects from more than 2,300 institutions from 36 countries are available on Europeana with numbers constantly rising. ${ }^{48}$ The content is socially connected in various sites and platforms, and also available through an iPad app. It is also downloadable and malleable under different copyright licensing regimes (such as the creative commons licences ${ }^{49}$ ). All metadata published by Europeana is available free of restrictions under the creative commons zero public domain dedication, ${ }^{50}$ although the mentioning of attribution is recommended ${ }^{51}$ In this sense, Europeana not only aggregates incredible amounts of content but builds an open, trusted source of cultural heritage, which is also meant to engage users in new ways of participating in their cultural heritage, and to facilitate knowledge transfer, innovation and advocacy in the cultural heritage sector.

Across the Atlantic, the Digital Public Library of America (DPLA) ${ }^{52}$ and the Digital Library of the Smithsonian ${ }^{53}$ are two analogous endeavours. Similarly to Europeana, the DPLA is a collaborative platform that enables new and transformative uses of America's digitized cultural heritage. It offers its application programming interface (API) and open data to software developers, researchers and others, who can create novel environments for learning, tools for discovery, and engaging apps. ${ }^{54}$

The above-mentioned initiatives, which are only a few of the various, public and private, digital library projects, point to the amazing opportunities of digital technologies and are cause for optimism about both cultural preservation and making cultural heritage a living, essential part of contemporary cultural processes. The possibilities of interfacing analogue and digital, connecting and managing metadata, ${ }^{55}$ as well as engaging the communities are truly unprecedented, although they do come with a host of problems and intricacies. ${ }^{56}$

\footnotetext{
${ }^{46}$ European Commission, Europeana: Next Steps, COM(2009) 440 final, 28 August 2009; also European Commission, i2010: Digital Libraries, COM(2005) 465 final, 30 September 2005.

${ }^{47} \mathrm{http}$ ://europeana.eu (last accessed 10 February 2014).

$48 \mathrm{http} / / /$ pro.europeana.eu/web/guest/about/facts-figures (last accessed 10 February 2014).

49 http://creativecommons.org/licenses/ (last accessed 10 February 2014).

50 http://creativecommons.org/publicdomain/zero/1.0/ (last accessed 10 February 2014).

${ }_{51} \mathrm{http}: / /$ pro.europeana.eu/usage-guidelines (last accessed 10 February 2014).

$52 \mathrm{http://dp.la} \mathrm{(last} \mathrm{accessed} 10$ February 2014).

${ }^{53}$ http://library.si.edu/digital-library (last accessed 10 February 2014).

$54 \mathrm{http}: / / \mathrm{dp} . \mathrm{la} / \mathrm{apps}$ (last accessed 10 February 2014).

${ }_{55}^{55}$ Geismar, supra note 25.

${ }^{56}$ For an excellent collection of papers on the digital return, see the special issues, "After the Return:

Digital Repatriation and the Circulation of Indigenous Knowledge", Museum and Anthropology
} 
Despite the general positivity around digitization projects like Europeana or the Digital Library of America, there are a number of challenges, which possibly reduce their impact and their sustainability. ${ }^{57}$ Some of them may be of technical character relating for instance to compatibility of different formats and standards, or to the availability and quality of metadata. Other concerns relate to the efficiency and the sustainability of such initiatives, as they demand the mobilization of substantial public or private funds. ${ }^{58}$ Most pertinently for this article, it should be stressed that many of the challenges are of a legal nature. Indeed, it could be maintained that these projects are possible in spite of the existing legal frameworks. The bulk of the problems come from copyright, which puts severe restrictions on digitization, for instance in dealing with orphan works, ${ }^{59}$ as well as limits on access to contemporary copyrighted works. Presently, the exemptions and limitations schemes in copyright do not enable digitized cultural preservation and retrieval efforts outside commercial market settings. In addition, digital technologies have allowed more effective control tools through technological protection measures, such as digital rights management systems (DRM), which restrict access to and use of digital copyrighted content and whose circumvention is prohibited by law. ${ }^{60}$

What we see in most of the digital libraries are works in the public domain. ${ }^{61}$ Many works in the grey area of law, where copyright can be challenged, are simply not shown to the public, so as to avoid expensive legal trials. Some types of content, such as audiovisual, which demand the clearance of packages of rights and not simply those of a single author or rights-holder, are almost completely absent from public digital collections. In At the end of the day, the user may be presented with a very skewed picture of our cultural heritage, and may indeed become disinterested if she or he does not have a particular passion for things created before the twentieth century. These issues are by no means

Review 7:1/2 (2013), available at http://scholarworks.iu.edu/journals/index.php/mar/issue/view/233 (last accessed 10 February 2014).

${ }^{57}$ For some early critique of the Europeana project, see Ricky Erway, "A View on Europeana from the US Perspective", Liber Quarterly 19:2 (2009), 103-121.

58 See e.g. Erway, supra note 57; Europeana Strategic Plan 2011-2015, available at http://www.pro.europeana.eu/c/document library/get file?uuid=c4f19464-7504-44db-ac1e-

3ddb78c922d7\&groupId=10602 (last accessed 10 February 2014).

${ }^{59}$ It is often difficult or impossible to locate the owner of copyright in a work for various reasons e.g. anonymous work; impossibility of tracing copyright through multiple transmissions, or because the owner's representative cannot be located. Such works are commonly called "orphan". It is impossible to negotiate over the use of such works. Potential users are reluctant to use orphan works in projects that would make the older works available to the public (such as in digital libraries). See e.g. David R. Hansen, "Orphan Works: Causes of the Problem" (Berkeley Digital Library Copyright Project, White Paper No 3, 2012) as well as the rest of the Berkeley Digital Library Copyright Project papers available at: http://www.law.berkeley.edu/12115.htm (last accessed 12 February 2014).

${ }^{60}$ Guy Pessach, "[Networked] Memory Institutions: Social Remembering, Privatization and its Discontents", Cardozo Arts and Entertainment Law Journal 26 (2008), 71-149, at 92-93. See also Guy Pessach, "Copyright Law as a Silencing Restriction on Non-Infringing Materials: Unveiling the Scope of Copyright Diversity Externalities", Southern California Law Review 76 (2003), 1067 -1104.

${ }^{61}$ Copyright is limited in time. After its expiry, the work becomes free for everyone to use - it enters the "public domain". The duration of copyright varies depending on the type of work, its publication status, and the place of first publication. For an excellent brief guide, see Peter B. Hirtle, Emily Hudson and Andrew T. Kenyon, Copyright and Cultural Institutions: Guidelines for Digitization for U.S. Libraries, Archives, and Museums (Ithaca, NY: Cornell University Library, 2009), at 39-54. 
trivial nor plainly technical and call for discussions with various stakeholders, so that solutions that serve both public and private interests are found.

\subsection{The question of access}

John Merryman has famously formulated the triad of cultural policy goals as preservation, truth and access. ${ }^{62} \mathrm{He}$ also clarified that these values should be considered in declining order of importance, so that if there is a conflict between preservation and access, ${ }^{63}$ preservation takes priority, and in a conflict between truth and access, truth trumps access. While preservation certainly remains important, also with intangible, digitized property, and property does not somehow lose its gravity as a concept, ${ }^{64}$ the value of access may have increased and may demand more policy attention and more actions to secure it.

While content may have proliferated under the conditions of the digital networked environment, this does not automatically mean that it is readily accessible. There are barriers of a different type. Some exist at the infrastructural level, such as no access to broadband Internet or failing networks. Others are implanted at the applications level, such as lack of interoperability between different types of platforms or software. A third category of barriers, very much in the sense of the issues we addressed in the preceding section, are placed at the content level - due to copyright protection or other obstructions imposed, for instance, through DRM. Increasingly important are also barriers of societal character, related to the digital literacy of the users. This can be thought of as a "second" digital divide, which goes beyond mere connectivity and presents a greater challenge. Digital literacy is broader and encompasses a set of skills needed to efficiently and effectively navigate in cyberspace, to create, contribute, distribute, access, use and reuse content. ${ }^{65}$ Although the use of digital media in contemporary societies is on the rise, there should not be an automatic presumption of digital literacy. ${ }^{66}$

All of these barriers impede access to cultural content, the engagement in active intercultural dialogue or various creative activities, thus distorting the conditions for a vibrant culturally diverse environment. The trouble with designing appropriate measures to dismantle these barriers to cultural content and foster participation is that they again, as noted earlier, fall into different, often disconnected, policy areas, and demand an integrated cultural policy agenda.

\footnotetext{
${ }^{62}$ John Henry Merryman, "The Nation and the Object", International Journal of Cultural Property 3:1 (1994), 61-76, at 64-65. See also John Henry Merryman, "The Public Interest in Cultural Property", California Law Review 77 (1989), 339-364.

${ }^{63}$ Merryman noted that while there may be many legitimate claims to access, "the object in question can only be in one place". Merryman (1989), at 360-361.

${ }^{64}$ See e.g. Robert E. Merges, "The Concept of Property in the Digital Age", Houston Law Review 45:4 (2008), 1239-1275.

${ }^{65}$ See e.g. Eszter Hargittai, "Digital Na(t)ives? Variation in Internet Skills and Uses among Members of the 'Net Generation'", Sociological Inquiry 80:1 (2009), 92-113.

${ }^{66}$ Renee Hobbs, Digital and Media Literacy: A Plan of Action (Washington, DC: The Aspen Institute, 2010), at 25 .
} 


\subsection{Thinking about our "memory institutions"}

Finally, I would like to stimulate our thinking about the future of global cultural law and policy by employing the concept of memory institutions, as developed by Guy Pessach. ${ }^{67}$

One can conceive of memory institutions as "social entities that select, document, contextualize, preserve, index, and thus canonize elements of humanity's culture, historical narratives, individual, and collective memories". ${ }^{68}$ Archives, museums and libraries are well-known examples of traditional memory institutions that have, over the years, become important hubs of cultural information, as well as curators of contemporary cultural processes. However, they have rarely functioned in interlinked ways, as analogue did not allow this, but rather they were single initiatives, which fought for the gains of network effects in attracting audience. In recent years, we have seen the emergence of new "networked memory institutions", in the form of online platforms, social networks, peer-to-peer file-sharing infrastructures, digital images agencies, online music stores and search engines' utilities. These institutions make use of the affordances of digital media, as sketched above, and in effect take up important derivative functions. "The preservation of digital artefacts covers now much more than the scope of tangible preservation by traditional memory institutions (museums, archives, libraries, and private collectors)", ${ }^{70}$ and becomes decentralized and dynamic involving also many private individual or community-based projects. ${ }^{71}$ Pessach highlights, among other things, two important trends in the remaking of our institutions of cultural remembering. The first is that most of them are "for profit" organizations, such as the Google Books Project, digital archives of newspapers and photographs or online music stores like Apple's iTunes and Rhapsody. These, even if presently functioning under free access, can change their business models and make access and use conditional on a payment. ${ }^{72}$ Second, the "fact that digitized cultural retrieval deals with intangible goods that are governed by copyright law stimulates the privatization of networked memory institutions through two accumulative tracks: (1) the commodification of digital cultural artefacts, including buyouts of copyright portfolios with cultural significance by commercial enterprises; [and] (2) copyright law's pressure on traditional public-oriented memory institutions (e.g., museums and libraries) to change their policies toward third parties who wish to access and use copyrighted, cultural works that such institutions posses and manage". ${ }^{73}$

\footnotetext{
${ }^{67}$ Pessach (2008), supra note 60.

${ }^{68}$ Pessach, ibid., at 73.

${ }^{69}$ Pessach, ibid., at 73 .

${ }^{70}$ Ibid., at 82 .

${ }^{71}$ Ibid., at $82-84$.

${ }^{72}$ Ibid., at 92-94, referring also to Rebecca Tushnet, "My Library: Copyright and the Role of Institutions in a Peer-to-Peer World", UCLA Law Review 53 (2006), 977-1029. See also along the same lines, Siva Vaidhyanathan, The Googlization of Everything: (And Why We Should Worry) (Berkeley, CA: University of California Press, 2011).

${ }^{73}$ Pessach, ibid., at 92.
} 
Overall, we see a process of remaking key cultural institutions in societies; the conditions of ensuring preservation, truth and access may be seriously affected in this process. It appears also that the public interest may not be adequately reflected in the present legal frameworks, at either the national or international levels.

\section{Concluding remarks}

The foregoing analysis has perhaps raised more questions than it has answered. The central argument this article sought to make is that the existing cultural policy instruments have not sufficiently considered the impact of digital technologies or have not done so at all. They are in effect still grounded in analogue/offline thinking and do not reflect the complex processes of contemporary cultural creation, distribution, consumption and preservation, as they evolve in the digital environment.

While the promise of "cloud culture", where there is more culture and it is more available to people than ever before, due to indefinite digital data storage, ubiquitous broadband, new search technologies and access through multiple devices $^{74}$ is a grand one, it comes with certain challenges attached. There is a need for a more granular understanding of the complex processes unfolding, which can provide a good basis for collective efforts in the public interest to ensure the preservation of and access to our cultural heritage in a sustainable manner. This may mean both less and more regulation, as for instance digital media reduce the thresholds for creativity and participation, while on the other hand, the digital may exacerbate the mismatch between non-economic and economic interests in cultural matters, especially as the current legal framework gives a priority to the protection of the latter.

\footnotetext{
${ }^{74}$ Charles Leadbeater, Cloud Culture: The Future of Global Cultural Relations (London: Counterpoint, 2010), at 36 .
} 